\title{
Proximate composition of rumen digesta from sheep slaughtered in Zuru Abattoir, Kebbi State, Nigeria
}

\author{
A. M. Sakaba ${ }^{1 \star}$, A. U. Hassan', I. S. Harande ${ }^{1}$, M. S. Isgogo', F.A. Maiyama² and B. M. Danbare ${ }^{3}$ \\ 1'Department of Animal Health and Production, Kebbi State College of Agriculture, PMB 1018, Zuru, Kebbi State, \\ Nigeria. \\ 2Department of Entrepreneurship Education, Kebbi State College of Agriculture, PMB 1018, Zuru, Kebbi State, Nigeria. \\ ${ }^{3}$ Department of Agricultural Technology, Kebbi State College of Agriculture, PMB 1018, Zuru, Kebbi State, Nigeria.
}

"Corresponding author. Email: aminsakaba@yahoo.com. Tel: +2348032917303.

Copyright @ 2017 Sakaba et al. This article remains permanently open access under the terms of the Creative Commons Attribution License 4.0, which permits unrestricted use, distribution, and reproduction in any medium, provided the original work is properly cited.

Received 9th August, 2017; Accepted 5th September, 2017

\begin{abstract}
Biochemical studies with a view to assess the proximate and essential mineral content of sun-dried rumen digesta were carried out. The values for each of the nutrients were collected in triplicates according to the samples analyzed. The results of mean percentages showed the samples contained moisture $(5.83 \pm 0.17)$, crude protein (15.52 \pm 0.20$)$, lipids $(5.17 \pm 0.17)$, fiber $(48.73 \pm 0.72)$, ash $(11.00 \pm 0.29)$ and carbohydrates $(19.98 \pm 0.32)$. The essential minerals were sodium (19.98 \pm 0.32$)$, potassium (4.73 \pm 0.18$)$, magnesium $(0.42 \pm 0.03)$, calcium $(0.45 \pm 0.03)$ and phosphorous (4.73 \pm 0.03$)$. The results indicated that rumen digesta from sheep slaughtered in Zuru metropolitan abattoir has nutritional qualities that could provide livestock producers with additional nutrients for enhanced animal nutrition. It is therefore recommended for livestock feeding trials in small ruminant production.
\end{abstract}

Key words: Abattoir, proximate composition, rumen digesta, sheep, waste.

\section{INTRODUCTION}

The slaughtering of animals produce essential animal protein in the form of meat for human consumption, this operation is usually carried out in the abattoir. An abattoir is an approved and registered place for hygienic slaughtering, processing, effective preservation, storage and distribution of meat products for human consumption and other industrial uses (Akinro et al., 2009).

The increase in population, urbanization and high demand for animal protein are in direct relationship. The drive to increase meat production for human consumption is attributed to various types of environmental pollutions due to improper practices and hygiene. Considerations are hardly given to safety practices during transportation, slaughtering and processing as such enormous wastes that impact negatively on the environment are produced (Adesemoye et al., 2006).

The wastes produced as a result of abattoir operations are generally termed as abattoir wastes that are either in solid or liquid form (Ayodele and Olufunmilayo, 2012). The solid among them include the condemned carcass, bones, horns, hair, aborted fetuses, faeces and digesta while the liquid are usually consisted of the dissolved solids, blood, gut content, urine and water. Improper disposal of these wastes products poses a serious problem to human health and environment (Amisu et al., 2003; Fearon et al., 2014).

Animal feed is an essential source of livestock production system which has great effect in the growth of livestock and quality of their products (Okoli et al., 2003). In the developing countries, the feed ingredients are in competition with man for food, this necessitates the search for locally available wastes or by-products to be recycled as livestock feed in order to arrest the situation. Recycling of abattoir wastes as feed stuff for livestock have been a continuous investigation due to global emphases on the use of non-conventional feedstuff in solving inadequate animal protein intake by humans (Agbabiaka et al., 2011). Feeding livestock with animal wastes result in reducing cost and makes possible the integration of livestock production which in turn reduces environmental pollution due proper disposal of abattoir wastes (Esonu et al., 2006). 
Rumen digesta is an abattoir waste that is partially digested forage found in the rumen. It is fairly rich in nutrients especially the crude protein that is essential for animal nutrition (Agbabiaka et al., 2011). The use of rumen digesta as feed supplementation could reduce cost, maximize profit and provide environmentally benign disposed of abattoir waste. Unfortunately, this useful practice has not been exploited in the study area. The use of rumen digesta as feed can only be achieved through a proximate analysis which is a biochemical assay chemical that gives an estimate of individual component of feedstuff (FAO, 2003).

Lack of information on the nutrients content of rumen digesta from small ruminants has limited its utilization as livestock feed in the study area. Therefore this study was designed to determine the nutrient composition of rumen digesta obtained from sheep slaughtered in Zuru metropolitan abattoir with a view to explore its potentials as an alternative feed resource.

\section{METHODOGY}

\section{Experimental site}

This study was conducted in the Department of Animal Health and Production, College of Agriculture Zuru, Kebbi State, Nigeria. Zuru is located within latitude $11^{\circ} 35^{\prime}$ and $11^{\circ} 55^{\prime}$ North and Longitude $4^{\circ} 45^{\prime}$ and $5^{\circ} 25^{\prime}$ East of the equator. It is geographically located in the Northern Guinea Savannah of the South-Eastern part of Kebbi State (KBSG, 2003). Zuru is the emirate headquarters of zuru emirate. It is located in the extreme South-Eastern part of Kebbi State and covers an area of of approximately 9,000 square kilometers. It is located on the hilly terrain and bounded to the North by Gummi Local Government Area of Zamfara State, North-East by Koko Local Government Area, South-West by Yauri Local Government Area, North-East by Bukkuyum Local Government Area of Zamfara State and South by Rijau Local Government Area of Niger state (Girma, 2008).

\section{Sample collection}

A total of 90 samples of rumen digesta from sheep were collected from Zuru metropolitan abattoir between May and June 2015. The collection of these samples coincides with the beginning of the rainy season in the study area. It is also the period when farmers in the area sell their small ruminants for the purchase of farm input. This makes sheep available for slaughter. The samples were sundried for seven days, and then 12 samples were subjected to laboratory analysis.

\section{Analytical procedure}

The proximate composition of sundried rumen digesta from sheep was analyzed as described by AOAC (2005).
Each sample was analyzed in triplicate. The crude protein was determined according to micro kjeldahl method using Macro Kjeldhal Digestion and Distillation Apparatus (Gerhardt, Germany) and by multiplying the nitrogen content with a factor 6.25. The crude fat was determined by soxhlet extraction method while soluble carbohydrates (NFE) by subtracting the sum of $\%$ ash, $\%$ crude fibre, \% crude fat and \% crude protein from 100. That is:

$$
\begin{aligned}
& \mathrm{NFE}=100-(\% \text { ash }+\% \text { crude fibre }+\% \text { crude fat }+ \\
& \% \text { crude protein })
\end{aligned}
$$

\section{Determination of minerals}

The mineral content of the digesta were analyzed as described by AOAC (2005). Potassium and sodium were determined by Photometric method (FP 640, Jeumeay) while phosphorous was determined through Vonado molybdate Yellow method using spectrometer Jenway 1315 UK. (UV-visible), and calcium, magnesium, iron, cupper and manganese were determined using Atomic Absorption Spectrometer (Buck 210, AAS).

\section{Data collection and statistical analysis}

The various nutrients and minerals analyzed in the laboratory were observed and their values were analyzed for descriptive statistics (Means \pm SE) using SPSS $20^{\text {th }}$ version as described by Aliyu et al. (2009).

\section{RESULT AND DISCUSSION}

The results for proximate and mineral analysis of sundried rumen digesta from sheep slaughtered in Zuru central abattoir are presented in Tables 1 and 2. The moisture content of the digesta was $5.83 \pm 0.17$ (Table 1). This value is lower than $14.48,16.1$ and 7.17 reported by Agbabiaka et al. (2012), Abouheif et al. (1999) and Dairo et al. (2005) respectively. The lower moisture content could be attributed to the processing methods of the sample before laboratory analysis. It is however an indication that sun-dried rumen digesta from sheep can be stored for a long period of time without deterioration. The value for crude protein $(15.52 \pm 0.2)$ from this study was the same with Abouheif et al. (1999). These values were however lower than 17.13 and 18.25 reported by Dairo et al. (2005) and Agbabiaka et al. (2012). Variation in the protein content could be attributed to the quality and diversity of the herbage material consumed by the animal, population and activity of the micro-organisms in the rumen in addition to the length of time the animal takes before slaughter after consumption of the forage material. The level of protein from this study indicated the potential of sun-dried rumen digesta from sheep as protein supplement in livestock nutrition. The crude fat 
Table 1. Proximate composition of sun-dried rumen digesta from sheep.

\begin{tabular}{lc}
\hline Nutrients & Mean composition (\%) \\
\hline Moisture & $5.83 \pm 0.17$ \\
Crude protein & $15.52 \pm 0.2$ \\
Lipids & $5.17 \pm 0.17$ \\
Fiber & $48.73 \pm 0.72$ \\
Ash & $11.00 \pm 0.29$ \\
Carbohydrates & $19.98 \pm 0.32$ \\
\hline
\end{tabular}

The values are presented in Mean \pm S.E.

Table 2. Mineral composition of sun-dried rumen digesta from sheep.

\begin{tabular}{lc}
\hline Minerals & Mean composition (\%) \\
\hline Sodium & $19.98 \pm 0.32$ \\
Potassium & $4.73 \pm 0.18$ \\
Magnesium & $0.42 \pm 0.03$ \\
Calcium & $0.45 \pm 0.03$ \\
Phosphorous & $4.73 \pm 0.03$ \\
\hline
\end{tabular}

The values are presented in Mean \pm S.E.

$(5.17 \pm 0.17)$, fibre $(48.73 \pm 0.72)$ and ash $(11.00 \pm 0.29)$ were greater than 2.1, 2.8 and 3.57 reported by Abouheif et al. (1999), Dairo et al. (2005) and Agbabiaka et al. (2012) respectively. The higher values of these nutrients could be explained by the silica content of grasses which reduce the ability of the herbivores to digest fiber due to increased tooth wear. The carbohydrates content $(19.98 \pm 0.32)$ was however lower than 40.8 and 38.13 reported by Dairo et al. (2005) and Agbabiaka et al. (2012) respectively. This is attributed to the sparing effect of carbohydrates. The values for these chemicals have indicated the ability of the sun-dried rumen digesta from sheep to provide the nutrients required for normal daily activities of livestock.

As shown in Table 2, the sodium $(2.44 \pm 0.01)$ and potassium $(4.73 \pm 0.18)$ obtained were greater than 3.92 and 0.21 reported by Basher et al. (2002) and Agbabiaka et al. (2012) respectively. The magnesium $(0.42 \pm 0.03)$, calcium $(0.45 \pm 0.03)$ and phosphorous $(4.73 \pm 0.03)$ obtained were lower than $4.1,8.2$ and 7.6 reported by Agbabiaka et al. (2012). The lower levels of minerals was an indication that the sun-dried rumen digesta from sheep alone cannot provide the minerals required by the animals thus supplementation becomes necessary for proper feed utilization and normal physiological function of the body.

\section{Conclusion and recommendations}

The results obtained from this study revealed that the sun-dried rumen digesta from sheep slaughtered in Zuru central abattoir contains vital nutrients that are required for livestock's normal physiological activities .It is therefore recommended that farmers in the study area should use it for livestock feeding trials. Furthermore, farmers should seek for more knowledge on the processing methods that will aid better utilization of the digesta as feed material to increase productivity. This study also recommended the proximate analysis in large ruminants kept for dairy and fattening purpose.

\section{CONFLICT OF INTEREST}

The authors declare that they have no conflict of interest.

\section{REFERENCES}

Abouheif, M. A. Kraidees, M. S., \& Al-Sebood, B. A. (1999). The Utilization of Rumen Content-Barley Meal in Diets of Growing Lambs. Asian-Aus. J. Anim. Sci., 12(8), 1234-1240.

Adesemoye, A. O., Opere, B. O., \& Makinde, S. C. O. (2006). Microbial content of Abattoir Wastewater and its Contaminated Soil in Lagos, Nigeria. African Journal of Biotechnology, 5(20), 1963-1968.

Agbabiaka, L. A., Madubuike, F. N., \& Amadi, S. A. (2012). Studies on Nutrients and Anti-Nurients of Rumen Digesta from Three Most Domesticated Ruminants in Nigeria. Pakistan Journal of Nutr., 11(7), 580-582.

Agbabiaka, L. A., Anukam K. U., \& Nwachukwu, V. N. (2011). Nutritive Value of Dried Rumen Digesta as Replacement for Soybean in Diets of Nile Tilapia (Oreochromis niloticus) Fingerlings. Pakistan Journal of Nutrition, 10(6), 568-571.

Akinro, A. O., Ologunagba, I. B., \& Yahaya, O. (2009). Environmental Implications of Unhygienic Operation of a City Abattoir in Akure, Western Nigeria. ARPN Journal of Engineering and Applied Sciences, 4(9), 60-63.

Aliyu, A. B., Musa, A. M., Sallau M. S., \& Oyewale, A. O. (2009). Proximate Composition, Mineral Elements and AntiNutritional Factors of Anisopus mannii N.E.Br. (Asclepiadaceae). Trends in Applied Science Research, Academic Journals Inc., 4(1), 68-72.

Amisu, K. O., Coker, A. O., On, S. L. W., \& Isokpehi, R. D. (2003). Arcobacter Butzlieri Strains from Poultry Abattoir Effluent in Nigeria. East African Medical Journal, 80, 218-221.

AOAC (2005). Official Methods of Analysis $18^{\text {th }}$ ed., Association of Official Analytical Chemist, Washington, DC.

Ayodele, A. A., \& Funmilayo, O. A. (2012). On Investigating Pollution of Groundwater from Attender Abattoir Wastes, Ogbomoso, Nigeria. International Journal of Engineering and Technology, 2(9), 1569-1585.

Basher, Y. A., Abubakar, A., \& Nasiru, M. (2002). Effect of Replacing Wheat Offal with Rumen digesta in the Diet of Cockerels. Proceedings of 27th Annual Conference, Nigeria Society of Animal Production, Pp. 164-166.

Dairo, F. A., Aina S. O. O., \&. Asafa, A. R. (2005). Performance Evaluation of Growing Rabbits Fed Varying levels of Rumen Content and Blood Rumen content Mixture. Nig. J. Anim. Prod., 32, 67-72.

Esonu, B. O., Ogbonna, U. D., Anyanwu, G. A., Emelanom, O. O., Uchegbu, M. C., Etuk, M. C., \& Udedibe, A. B. I. (2006). Evaluation of Performance, Organ Characteristics and 
Economic Analysis of Broiler Finisher Fed Dried Rumen Digesta. Int. J. Poult. Sci., 5, 1116-1118.

FAO (2003). Food energy-methods of Analysis and Conversion Factors: Food and nutrition paper. Technical Workshop, Rome.

Fearon, J., Mensah, S. B., \& Boateng, V. (2014). Abattoir Operations, Waste Generation and Management in the Tamale Metropolis: Case Study of the Tamale Slaughterhouse. Journal of Public Health and Epidemiology, 6(1), 14-19.

Girma, S. A. (2008). Agro-climatology of Millet Production in Desert Fringe Zone of Nigeria, A case study of Kebbi State. Unpublished M. Sc. Thesis. Federal University of Technology Minna, Niger State. p. 97.
KBSG (2003). Kebbi State Government Official Diary. Directorate of Information Kebbi State, Nigeria.

Okoli, I. C., Anunobi, M. O., Obua, B. E., \& Enemuo, V. (2003). Studies on selected browses of southeastern Nigeria with particular reference to their proximate and some endogenous anti-nutritional constituents. Livestock research for rural development, 15(9), 3-7. 